\title{
EXPERIMENTS REGARDING THERMAL AND MECHANICAL DEFORMATIONS OF CONTINUOUS CAST STEEL WIRE
}

\author{
Marian BORDEI, Bogdan CARP \\ "Dunarea de Jos" University of Galati, Romania \\ e-mail: marian.bordei@ugal.ro
}

\begin{abstract}
During the casting process, the crust of the steel wire is permanently subjected to thermo mechanical stresses (temperature variations, pulling, bending and straightening forces, ferrostatic pressure), which, when exceeding the deformation capacity of the crust, can lead to cracks.

Therefore, it is necessary to know what kind of stresses act on the crust and how the steel behaves at high temperatures at certain process parameters (extraction speed, cooling intensity, etc.)
\end{abstract}

KEYWORDS: continuous casting, solidification, mechanical stresses

\section{Introduction}

In order to highlight the behaviour of the steel during the deformation that takes place during solidification, for straightening the wire or for its deformation in the continuous casting installation, it is necessary to know the mechanical properties of the cast steel at temperatures close to the solidification temperature. The experiments performed allow the simulation of the thermal and mechanical deformations to which the solidified crust of the steel wire is subjected in the continuous casting machine.

On the technological flow of manufacturing flat products, the sheet billets are casted and then hot rolled; these operations take place in a temperature range between the melting temperature and approx. $600{ }^{\circ} \mathrm{C}$ [7]. Due to the interaction of thermal, mechanical and chemical factors during the processes of solidification and plastic deformation, the plasticity shows an uneven variation as the temperature decreases. During the experiments we performed tensile tests on OL 37-4k steel samples (S235J2G4, according to EURONRM 10025) in the mentioned temperature range.

The cause of the formation of cracks that appear on the surface of continuously cast slabs is found in the fragility of steel corresponding to temperature ranges. These areas (characteristic for each type of steel) - in which the plasticity of the steel is reduced were determined by tensile tests at different temperatures.

Knowing the deformation conditions of steel - at temperatures close to solidus temperature - leads to the possibility of finding technical solutions to reduce the risk of internal cracks appearance and technologies and equipment achievement that suggest the reduction of the continuous cast wire thickness on the incompletely solidified area [4].

There are two types of experimental methods: a method that involves measuring critical stresses (in which internal cracks appear) on laboratory stand in order to simulate the conditions of casting and plastic deformation, (e.g.: simulators Wumsi, Gleeble, etc. $[5,7])$ and a method that involves determining the mechanical properties at high temperature, using tension test machines.

In order to simulate the deformation process of the continuously cast steel wire, we considered representative the thermal cycle through which the steel is brought into the molten state, being then cooled to the temperature at which the test is performed. During the experiments we followed the dynamics of steel deformation in the biphasic area, where the behavior of the liquid steel wire can be the cause of fragility and the premise of the development of internal cracks [4].

\section{Experimental conditions}

The tests were performed on an experimental stand for high temperature tensile tests, consisting of a universal hydraulic material testing machine, to which a high frequency generator $(150 \mathrm{kHz}, 25 \mathrm{~kW})$ was attached for heating the samples, Figure 1. 


\section{THE ANNALS OF "DUNAREA DE JOS” UNIVERSITY OF GALATI \\ FASCICLE IX. METALLURGY AND MATERIALS SCIENCE \\ No. 2 - 2020, ISSN 2668-4748; e-ISSN 2668-4756 \\ Article DOI: $\underline{\text { https://doi.org/10.35219/mms.2020.2.03 }}$}
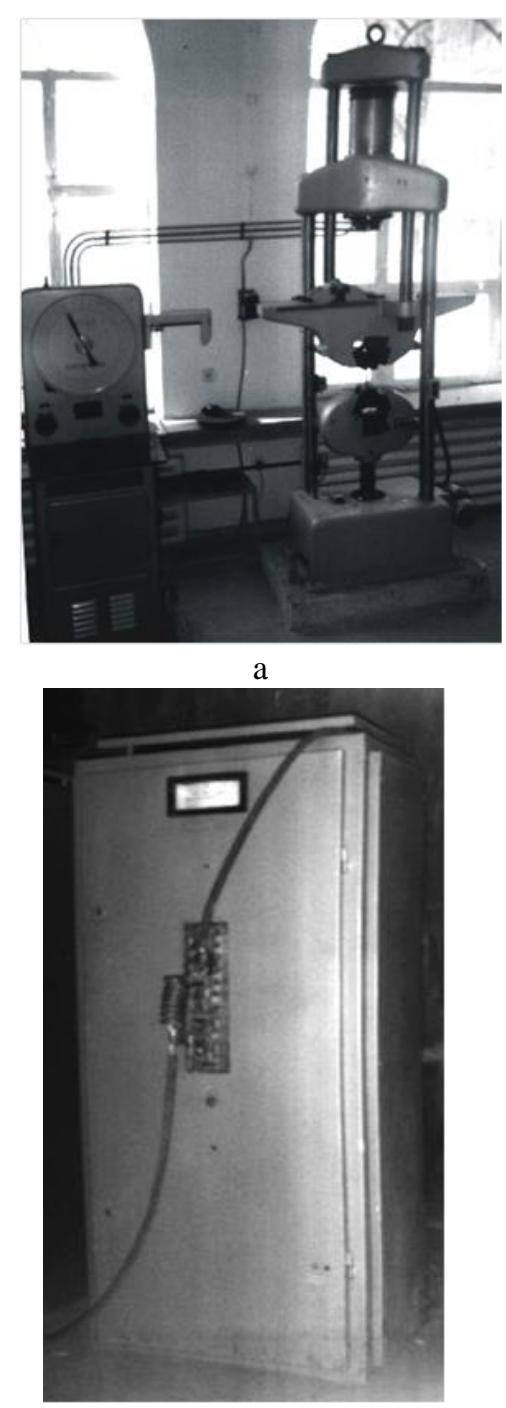

$\mathrm{c}$

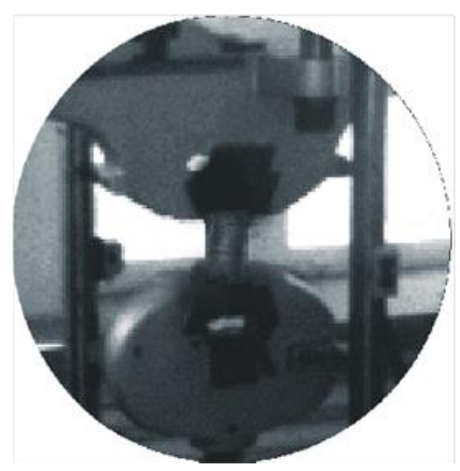

$\mathrm{b}$

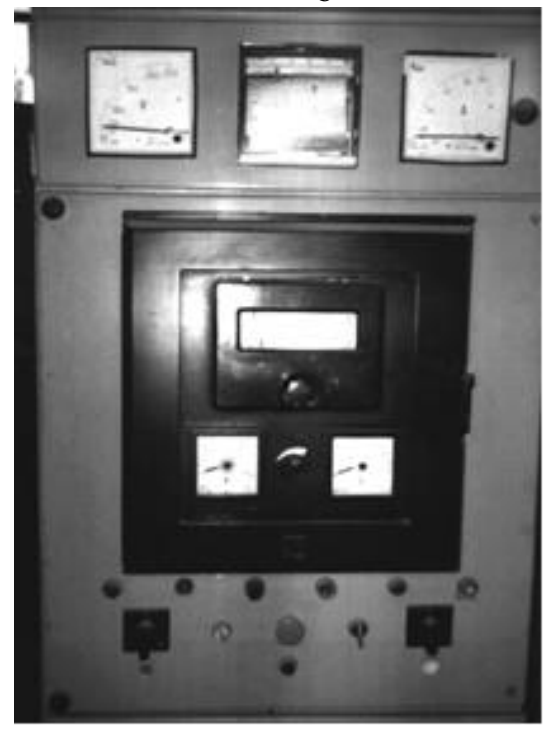

d

Fig. 1. Experimental stand used to perform tensile tests at high temperatures: a. tension traction machine; b) detail; $c$. high frequency generator; $d$. control panel

The dimensions of the samples used: diameter $\mathrm{d}$ $=20 \mathrm{~mm}$; the area of the initial section $\mathrm{S}_{0}=314.2$ $\mathrm{mm}^{2}$; length of the calibrated portion $\mathrm{L}_{\mathrm{c}}=110 \mathrm{~mm}$; length between marks $\mathrm{L}_{0}=100 \mathrm{~mm}$ ( $\mathrm{L}_{0}=\mathrm{k} \cdot \sqrt{\mathrm{S}_{0}} ; \mathrm{k}=5.65$, corresponding to proportional samples); length of the heated portion $\mathrm{L}_{\mathrm{t}}$ $=30 \mathrm{~mm}$.

The samples were heated to the melting temperature of the steel, respectively $1550{ }^{\circ} \mathrm{C}$, cooled to $10^{\circ} \mathrm{C} / \mathrm{s}$ and, after maintaining the test temperature for 120 seconds, tensile tests were performed. The flow of steel in the molten area is stopped by its surface tension.

The chemical composition of the samples used (steel S235J2G4, according to EURONRM 10025) is given in Table 1.

Table 1. The chemical composition of the samples used (steel S235J2G4)

\begin{tabular}{|c|c|c|c|c|c|c|c|}
\hline \multicolumn{7}{|c|}{ Chemical composition, [\%] } \\
\hline $\mathbf{C}$ & $\mathbf{M n}$ & $\mathbf{P}$ & $\mathbf{S}$ & $\mathbf{S i}$ & $\mathbf{A l}$ & $\mathbf{C r}$ & $\mathbf{N i}$ \\
\hline 0.10 & 0.82 & 0.04 & 0.04 & 0.15 & 0.03 & 0.20 & 0.16 \\
\hline
\end{tabular}


The temperature was measured with two $\mathrm{Pt} / \mathrm{Pt}$ Rd thermocouples, glued on the samples subjected to traction, at the upper and lower limit of the molten area, respectively (in order to follow its uniformity on the whole portion subjected to heating).

\section{The behaviour of the steel wire at alternating stresses (on the route of the casting machine)}

The structural transformations that take place in the continuously cast steel wire (grain finishing, ferrite fractionation, etc.) depend on the thermal cycles to which it is subjected. Transverse cracking is one of the biggest problems characteristic of continuous casting on vertical curved wire machine. This type of crack is generally formed along the oscillation traces, their propagation taking place due to the stresses that occur when straightening the steel wire, especially since this operation takes place in the temperature range of $1000-700{ }^{\circ} \mathrm{C}$, which comprises two of the three fragility areas of the steel [1].

The thermal cycle to which the wire surface is subjected is produced by the alternating action: cooling (cooling water and contact with the rollers), heating (heat transfer inside the wire).

The concepts of simulation are relatively close to industrial conditions. In this regard, attention is paid to the fact that the surface layer, initially solidified (solidified crust), is periodically subjected to a cycle of tensile / compressive forces, as a result of cooling and reheating and as a result of swelling of the steel wire between the support-driving rolls of the continuous casting machine (due to the ferrostatic pressure of the steel).

During the experiments, the samples, cooled to ambient temperature, are subjected to alternative traction forces, the criterion for assessing the test being the number of cycles leading to their destruction. The purpose of the test is to determine the probability of surface cracks occurring, and, if they occur, to assess at what point in the process they occur.

The temperature ranges in which the solidified crust exhibits a low resistance capacity to alternating tension / compression stresses can be determined for each type (class) of steel.

Periodic forces can lead to the accumulation of stresses, the cyclic deformation produced having the effect of cracking the steel crust [1].

According to these premises, during the testing, we applied sinusoidal deformation cycles to the samples with a period of 15 seconds, at different temperatures, corresponding to those in the continuous casting process, the values of the deformation amplitude varying by $1 \%$.

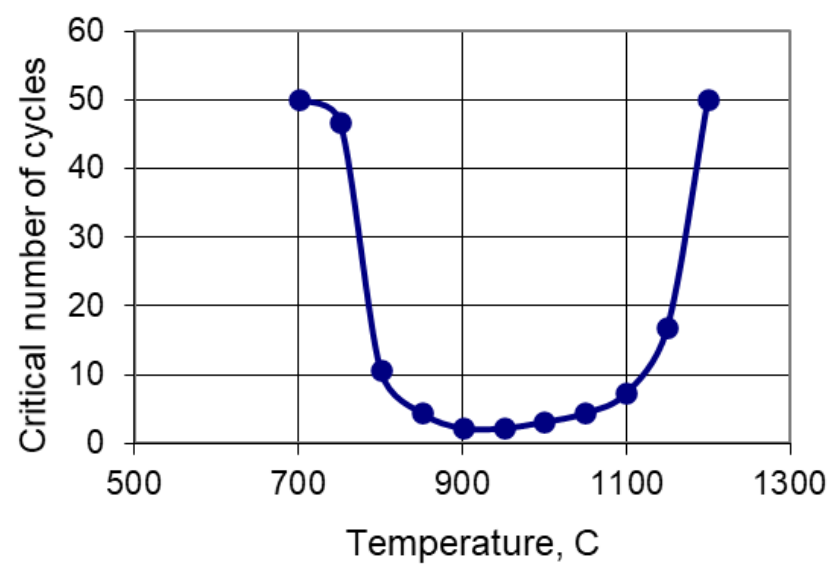

Fig. 2. The critical number of cycles at which cracks occur

Figure 2 shows the results obtained when testing the steel. It can be noticed that the possibility of cracking occurs after only 3-4 cycles. Regarding the way in which the rupture occurred, an exclusively intercrystalline crack of minimum resistance is observed, the surfaces of the grain being covered with small depressions containing sulphur particles.

It is also noticeable the extension of the critical temperature range for the studied steel, at 750-1150 ${ }^{\circ} \mathrm{C}$.

\section{Conclusions}

Sulphur precipitates at the grain limit: the ratio of $\mathrm{Mn} / \mathrm{S}$ content is 8 , in the case of the analysed steel. At the relative decrease of the manganese content in comparison with the sulphur content, smaller amounts of manganese sulphide precipitate during solidification. The solubility of sulphur decreases sharply in the lower austenitic zone while iron sulphide precipitate at the edges of the grain. 


\section{THE ANNALS OF "DUNAREA DE JOS” UNIVERSITY OF GALATI \\ FASCICLE IX. METALLURGY AND MATERIALS SCIENCE \\ $\mathrm{N}^{\circ} .2$ - 2020, ISSN 2668-4748; e-ISSN 2668-4756 \\ Article DOI: https://doi.org/10.35219/mms.2020.2.03}

Carbon content: to the extension of the critical temperature range also contributes the carbon content which is, for the analysed steel, in the critical range $(0.12-0.14 \%)$.

\section{References}

[1]. Bordei M., Considerente privind deformarea plastică a semifabricatelor turnate continuu în scopul optimizării unor parametri ai proceselor de turnare continuă-laminare, $\mathrm{PhD}$ thesis, Galati, 2000.

[2]. Bordei M., Chiriac A., Ciocan A., Ivan I., Control of Slab Narrow Face Bulging in Continuous Casting, Analele Universităţii
„Dunărea de Jos” din Galaţi, Fascicula IX Metalurgie şi Ştiința Materialelor, 1997.

[3]. Cazimirovici E., Teoria deformărilor plastice, Ed. didactică şi pedagogică, Bucureşti, 1981.

[4]. Bordei M., Cercetări privind obţinerea tablelor cu grosimi de $50-80 \mathrm{~mm}$ din brame turnate continuu, Contract cercetare $\mathrm{nr}$. 37/1992; beneficiar: Sidex S.A. Galaţi.

[5]. Ferguson H. S., Physical modelling of continuous casting, Steel Technology, Anglia, p. 151-154, 1994-1995.

[6]. Fleming G., Turnarea continuă de benzi CSP-alternativă de viitor pentru modernizarea productiei de brame, Prospect SMS.

[7]. Tsubakiharo O., Tehnologii care au fãcut posibilă cuplarea turnării continue cu laminarea la cald, Transaction of the Iron and Steel Institute of Japan, 2/1987. 